\title{
Regional and annual variability in common eider nesting ecology in Labrador
}

\author{
Keith G. Chaulk, Gregory J. Robertson, \\ \& William A. Montevecchi
}

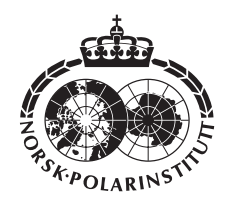

\begin{abstract}
Nesting densities are often used to estimate breeding population size and with other measures of reproductive performance can be useful indicators of population status. These aspects of breeding biology often show considerable spatial and temporal variation. Between 2000 and 2003, we surveyed nesting common eiders (Somateria mollissima) on 172 islands in three archipelagos (Nain, Hopedale, Rigolet) on the Labrador coast. Rigolet was the largest archipelago $\left(2834 \mathrm{~km}^{2}\right)$ followed by Nain then Hopedale, and island density varied inversely with archipelago size. Overall means were: nest density $52.0 \pm 141.9$ (SD) nests/ha; nest initiation 12 June \pm 12 days; clutch size $3.7 \pm 1.2$ eggs/nest; egg volume $98.8 \pm 10.4 \mathrm{~cm}^{3}$; and clutch volume $392.3 \pm 135.0 \mathrm{~cm}^{3}$. Rigolet had the highest average egg volumes and nest densities, the highest single island nest density of 1053 nests/ha, and the earliest average nest initiation date. We found significant differences in nest densities among archipelagos and across years; significant archipelago and year interactions were detected for nest initiation date and clutch size. Significant differences were found among individual islands for all response variables except egg volume. For egg volume, within-archipelago island differences were not significant, but between-archipelago differences were significant. Thus egg volume may be a useful diagnostic to identify population affiliation.
\end{abstract}

K. G. Chaulk, Labrador Inuit Association, Box 382 Station "C', Goose Bay, Labrador, NL, Canada A0P 1C0, kchaulk@nunatsiavut.com; G. J. Robertson, Canadian Wildlife Service, 6 Bruce Street, Mount Pearl, Newfoundland, NL, Canada AIN 4T3; W. A. Montevecchi, Department of Psychology, Memorial University of Newfoundland, St. John's, Newfoundland, NL, Canada A1B $3 X 9$.

Understanding regional and annual variation in the breeding ecology of organisms is important for conservation and management purposes. Variable expression of ecological characteristics often occurs in response to change in the environment where organisms live. Breeding ecology can be influenced by biophysical factors at differing temporal and spatial scales (Scott et al. 2002). Aspects of avian ecology such as nest density, clutch size, and egg volume can be influenced by population dynamics, population genetics, habitat quality, and/or food availability (Lack 1967; Ryder 1970; Robertson et al. 2001; Hario \& Selin
2002). Furthermore some components of breeding ecology may be prone or resistant to annual and/or regional fluctuations in the biophysical environment (Avise \& Hamrick 1996; Erikstad, Tveraa et al. 1998; Bregnballe 2002; Hario \& Selin 2002).

Common eiders (Somateria mollissima) are an important species for many northern peoples, as a source of meat, eggs and down. These birds exhibit substantial variation in the timing of nesting, nesting density, clutch size and other aspects of their breeding ecology (Goudie et al. 2000; Robertson et al. 2001; Chaulk et al. in press). Under- 
standing patterns of annual and regional variation in eider breeding performance can be very important for management and conservation purposes. Early nest initiation dates and large clutch sizes are generally indicative of favourable breeding conditions, while nesting densities are often used to estimate breeding population size. Unfortunately most eider research is limited in spatial and/or temporal scope, and the rare papers that contain multi-year and/or multi-site comparisons, are generally from temperate climes in northern Europe (Milne 1974; Swennen 1983; Coulson 1984, 1999; Hario Selin 1988; Bregnballe 2002; Hanssen et al. 2003).

The goal of this paper was to examine annual and regional variation of common eider nesting ecology at three distinct sites on the mid-Labrador coast, a subarctic region, over a four-year period (2000 to 2003). In this paper, we investigate nest density, nest initiation, clutch size, egg and clutch volume. In general we expected both regional and annual variation in most nesting characters, as these traits have been shown to vary in eiders. Of greater interest was wheth- er annual patterns of variation were maintained across regions, or whether traits varied independently within regions across the years.

\section{Study area}

Archipelagos near the communities of Nain, Hopedale and Rigolet were surveyed from 2000 to 2003 (Fig. 1). The extent of each archipelago was determined by calculating a minimum convex polygon (Mohr 1947) containing all islands that were completely searched. The total geographic area of the three archipelagos was estimated to be $4785 \mathrm{~km}^{2}$, and contained approximately of 1600 islands (Table 1). The archipelago adjacent to Rigolet covered the largest geographic area while the archipelago adjacent to Hopedale was the smallest (Table 1). Overall the average size of islands within the three archipelagos was 30.1 ha \pm 288.8 ( $1 \mathrm{SD}$ ); on average the largest islands were found in the Rigolet archipelago (Table 1). The greatest island density occurred in the Hopedale archipelago $\left(0.90\right.$ islands $\left./ \mathrm{km}^{2}\right)$ fol-

Table 1. Location, island characteristics, sampling intensity and sampling dates of archipelagos in Labrador where data were collected on nesting ecology of common eiders (Somateria mollissima), 2000-2003.

\begin{tabular}{|c|c|c|c|c|}
\hline & Nain & Hopedale & Rigolet & All \\
\hline \multicolumn{5}{|l|}{ Study area location } \\
\hline Mean latitude $\left({ }^{\circ} \mathrm{N}\right)$ & 56.36 & 55.33 & 54.18 & \\
\hline Mean longitude $\left({ }^{\circ} \mathrm{W}\right)$ & 61.06 & 59.81 & 57.41 & \\
\hline Study area size $\left(\mathrm{km}^{2}\right)$ & 1151 & 800 & 2834 & 4785 \\
\hline Study area perimeter $(\mathrm{km})$ & 145 & 128 & 278 & 551 \\
\hline $\mathrm{N}$ (islands) in study area & 497 & 720 & 335 & 1552 \\
\hline $\begin{array}{l}\text { Island density } \\
\text { (islands } / \mathrm{km}^{2} \text { ) }\end{array}$ & 0.43 & 0.90 & 0.12 & 0.32 \\
\hline \multicolumn{5}{|l|}{ Archipelago island size } \\
\hline mean \pm 1 SD (ha) & $33 \pm 318$ & $20 \pm 194$ & $47 \pm 394$ & $30 \pm 289$ \\
\hline Range (ha) & $0.01-6903$ & $0.02-3875$ & $0.02-5204$ & $0.01-6903$ \\
\hline \multicolumn{5}{|l|}{ Size sampled islands } \\
\hline Mean \pm 1 SD (ha) & $1.3 \pm 1.5$ & $1.6 \pm 2.6$ & $4.1 \pm 10.2$ & $2.3 \pm 6.0$ \\
\hline \multicolumn{5}{|l|}{ Island sampling scheme } \\
\hline No. one year only & 13 & 33 & 17 & 63 \\
\hline No. two years only & 11 & 19 & 15 & 45 \\
\hline No. three years only & 10 & 14 & 12 & 36 \\
\hline No. all four years & 8 & 13 & 7 & 28 \\
\hline Survey dates 2000 & 3-9 July & 28-30 June & 20-26 June & 20 June-9 July \\
\hline Survey dates 2001 & 5-19 July & 4-17 July & 18-27 June & 18 June-19 July \\
\hline Survey dates 2002 & 13-22 July & 3-17 July & 17-22 June & 17 June-22 July \\
\hline Survey dates 2003 & 11 - 13 July & 3-7 July & 14-20 June & 14 June - 13 July \\
\hline
\end{tabular}


Fig. 1.: General location of archipelagos surveyed between 2000 and 2003 on the Labrador coast.

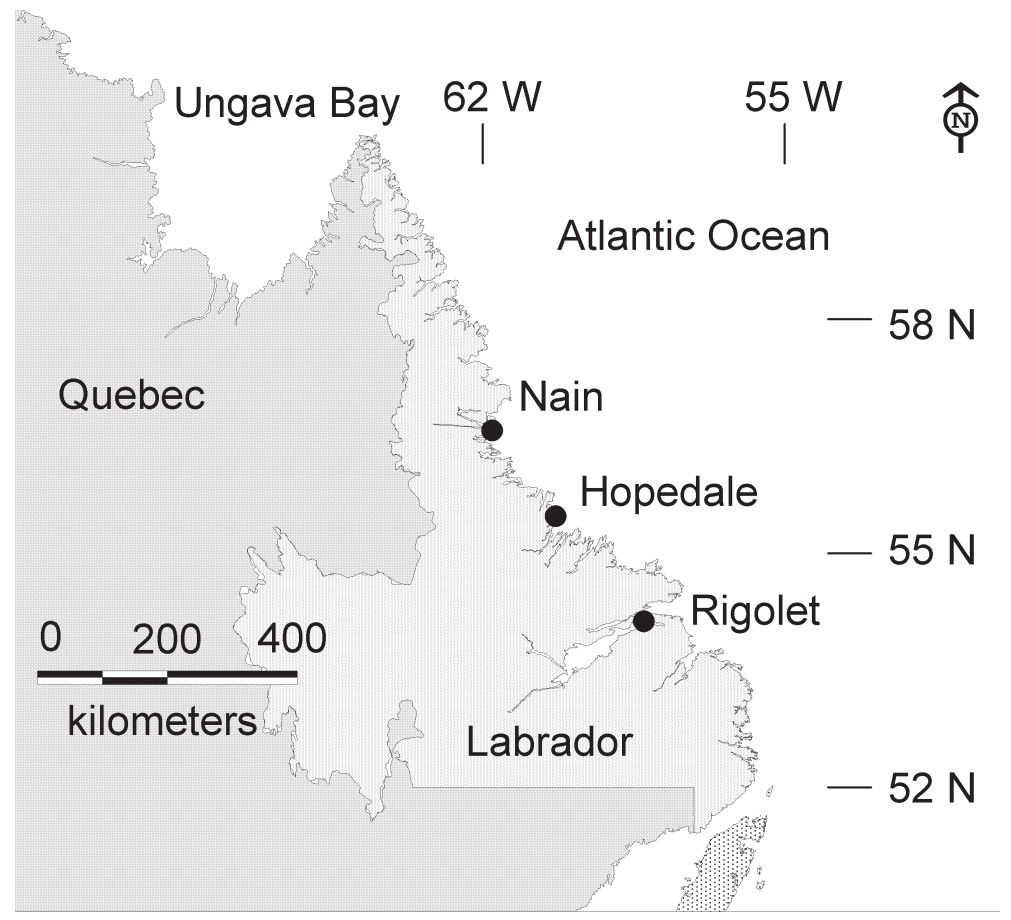

lowed by Nain then Rigolet (Table 1).

All archipelagos shared similar environmental characteristics such as a northern maritime climate, vegetation composed primarily of mosses, lichens, forbes, grasses, and sedges. The archipelagos were typically comprised of barren islands with sparse vegetation and very limited nesting cover. Islands in the Rigolet area had denser and taller ground vegetation, and on some islands woodier cover, including stunted black spruce (Picea mariana). All three archipelagos are classified as coastal barrens (Lopoukhine et al. 1978), are considered to have a High Boreal ecoclimate (Meades 1990) and a Low Arctic oceanographic regime (Nettleship \& Evans 1985). On the central and northern Labrador coast the concept of discrete archipelagos is somewhat misleading, as the island complex along this coast is for the most part continuous. The island complexes, hereafter referred to as archipelagos, selected for study were typical of this portion of the Labrador coast.

\section{Methods}

From 2000 to 2003 we surveyed three archipelagos (Nain, Hopedale, Rigolet) for nesting eiders. Islands were selected for study on the basis of random sampling. In all cases we limited our searches to islands that were estimated to be smaller than 30 ha. Analysis of the spatial distribution of our data set show that our samples were spatially random within the subset of islands that were less than 30 ha within each archipelago (K. G. Chaulk unpublished data). Ground surveys were conducted using standard search methods employed by the Canadian Wildlife Service (Nettleship 1980) and other researchers (Falardeau et al. 2003; Merkel 2004; Chaulk et al. in press); these consisted of two to four people walking linearly over the islands searching for signs of eider nesting. Islands in the three archipelagos were for the most part barren with limited nest-cover; hens and unattended nests were easily detected. Archipelagos were searched at approximately the same time each of the four years (Table 1). For the most part the senior author conducted all surveys, the exception being Nain and Hopedale in 2001 and 2002, where the senior author initiated the surveys but the field crew completed them.

For each common eider nest observed, information was recorded on apparent clutch size, nest age, and nest status. Nests were classed as follows: incubating - current season nest containing 
eggs; hatching - at least one chick was breaking its shell; hatched - at least one chick was completely out of its shell; depredated - broken and bloody eggs were present in or immediately adjacent to the nest; and unknown - nest was in disrepair with no eggs or signs of depredation.

The incubation period was assumed to be 24 to 26 days (Goudie et al. 2000), with incubation generally commencing after the laying of the penultimate egg (Hanssen et al. 2002). Candling was used to age the eggs (Weller 1956) and to calculate nest initiation we added the number of eggs to the egg age and we subtracted this number plus one from the survey date. Nests with more than six eggs were not aged. Apparent clutch sizes were calculated using nests classified as incubating; nests with more than six eggs are generally considered dump nests produced by two or more females (Swennen 1983; Robertson 1995) and were omitted from the analysis. Due to lack of data, nest initiation dates were not calculated for the 2001 breeding year.

With respect to egg size measurements we randomly selected a subset of previously surveyed islands, and on these we randomly selected nests and eggs for further investigation. Each randomly selected egg was then measured using Vernier calipers: egg length was measured from pole to pole, and width was measured at the widest part of the egg; all measurements were recorded in $\mathrm{mm}$. Egg volume was calculated based on the formula presented by Guild (1974) and Robertson et al. (2001); clutch volume was estimated only for nests for which we had data on egg volume and clutch size. Clutch volume was estimated as clutch size multiplied by the estimated egg volume for a given nest.

Island nest densities were calculated using islands that were completely searched. Island sizes were derived from digital 1:50000 base maps for the Labrador coast. Geodetic coordinates are reported as latitude and longitude, decimal degrees, North
American Datum 1983. Nest density, nest initiation, and clutch size were analysed using a general linear model, with the year, archipelago and its interaction as fixed factors. Island, nested within archipelago, was also included as a random factor to control for multiple measurements of islands across years. Egg volumes and clutch volumes were analysed with one-way ANOVA, with archipelago as a fixed factor and island, nested within archipelago, as a random factor. Critical alpha was set at 0.05 for all tests, which were all two-tailed.

\section{Results}

We sampled 172 islands in the three archipelagos with the greatest island sampling effort expended in Hopedale (Table 1). The average size of sampled islands was $2.3 \pm 6.0$ ha (Table 1). On the islands that were completely searched we counted 10962 eider nests and these contained 35401 eggs. Overall, on average there were 52 nests/ha or 172 eggs/ha (Table 2). The highest nest counts were observed in Rigolet; one island had 654 nests, and another island, 0.18 ha in size, had the equivalent of 1053 nests/ha. For island nest-density both archipelago and year were significant factors, although they did not show statistically significant interaction (Table 3). There appeared to be greater between-archipelago variation than between-year variation in nest density (Fig. 2).

The overall average nest initiation date was 12 June, the earliest average nest initiation dates occurred in the south at Rigolet (3 June) and the latest in the north at Nain (23 June) (Fig. 3 ). However, we detected a significant interaction between archipelago and year for nest initiation date (Table 3, Fig. 4). The overall average clutch size was $3.7 \pm 1.2$ eggs/nest (Table 2). The largest average clutch size was observed in Hopedale at $3.8 \pm 1.2$ eggs, followed by Rigolet at $3.7 \pm 1.2$ eggs, and Nain at $3.6 \pm 1.2$ eggs; howev-

Table 2. Mean ( $\pm 1 \mathrm{SD})$ and ranges of nesting traits of common eiders breeding in Labrador, 2000-2003.

\begin{tabular}{llll}
\hline & Period & N & Mean \\
\hline Nest density (nests/ha) & $2000-03$ & 331 & $52.0 \pm 141.9$ (range $=0-1053)$ \\
Nest initiation & $2000,02-03$ & 272 & 12 June \pm 12 d (range $=21$ May to 9 July) \\
Clutch size & $2000-03$ & 10137 & $3.7 \pm 1.2($ range $=0-6)$ \\
Egg volume $\left(\mathrm{cm}^{3}\right)$ & 2003 & 415 & $98.8 \pm 10.4($ range $=61.0-160.0)$ \\
Clutch volume $\left(\mathrm{cm}^{3}\right)$ & 2003 & 415 & $392.3 \pm 135($ range $=77.2-1008.4)$ \\
\hline
\end{tabular}


Fig. 2.: Interval plot of mean nest density (nests/ha) by archipelago and year with $95 \%$ CI.

Horizontal line is equal to the overall mean.
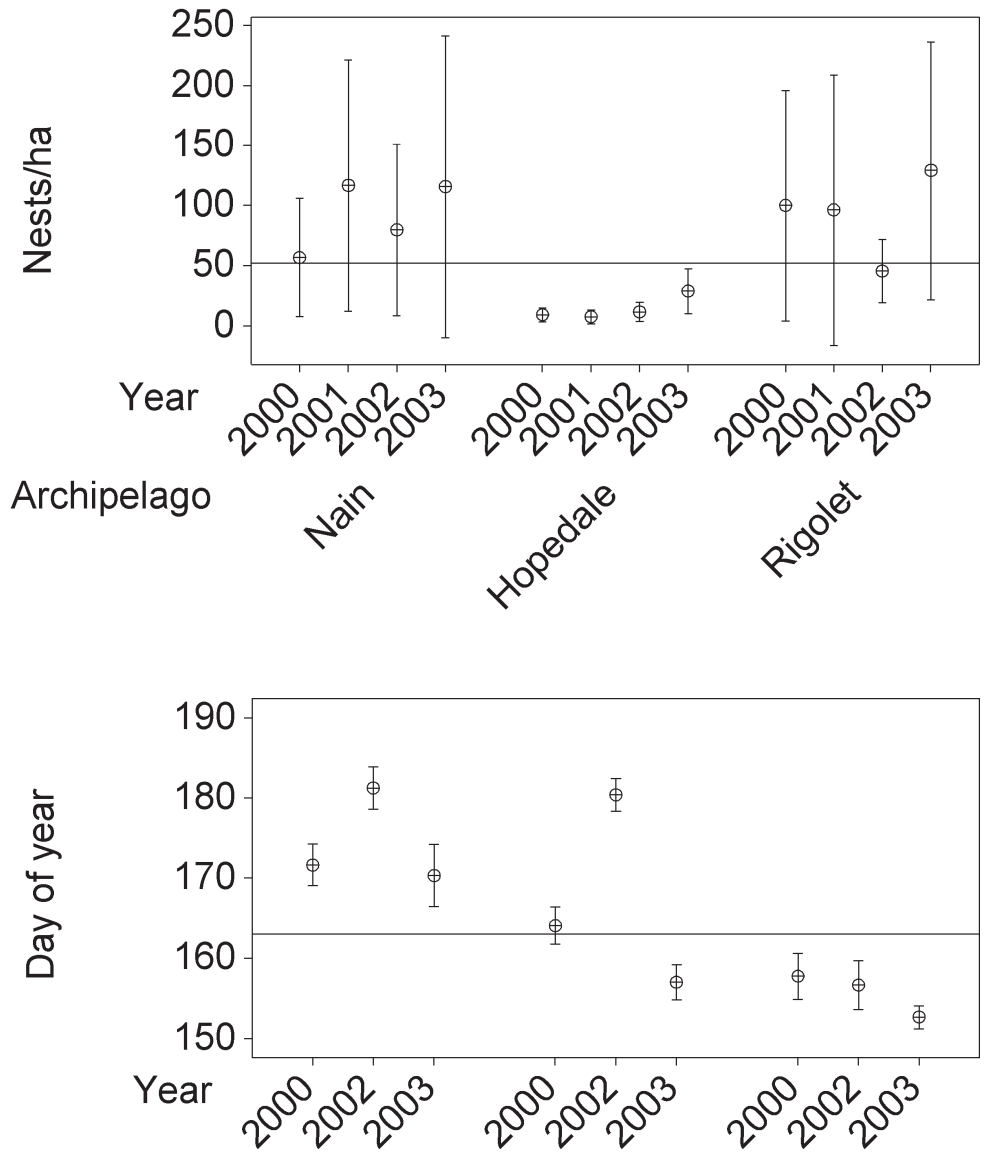

Archipelago
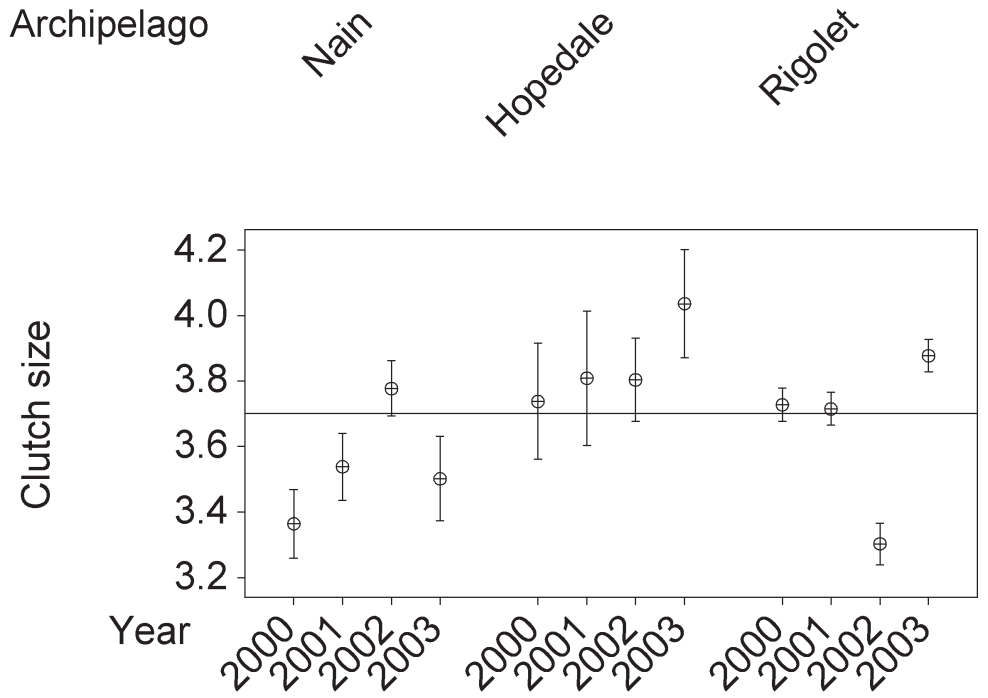

Archipelago

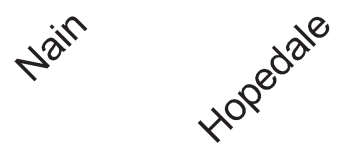

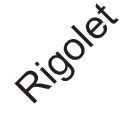


er, we detected a significant interaction between archipelago and year for clutch size (Table 3, Fig. 4). Egg volume varied significantly among archipelagoes but not across individual islands (Table 3 ). The largest egg volume was observed in Rigolet and the smallest in Nain (Fig. 5). The largest clutch volume was observed in Hopedale (Table 2, Fig. 5) although the differences among archipelagos were not significant (Table 3 ).

\section{Discussion}

The highest nest density that we observed occurred in Rigolet (1053 nest/ha). This observation was made on a small island approximately 0.18 ha, and is high relative to nest densities reported elsewhere. For example, $S . m$. borealis typically nest at low nest densities ( 0.8 to 4.5 nests/ha; Cooch 1986), though there are some exceptions, such as East Bay, Southampton Island (Abraham \& Finney 1986). Nest densities for $S$. $m$. dresseri in the St. Lawrence River averaged 3 nests/ha, but reached as high as 741.5 nests/ha (Chapdelaine et al. 1986). Nesting densities are probably influenced by numerous interacting local factors, including — but not limited to - available nesting islands and brood rearing areas, predators, disturbance, and overall population size.

Previously, we also observed significant differences in nest densities among archipelagos across a larger geographic range in Labrador, but were not able to examine annual variation (Chaulk et al. in press). The present analysis suggests that annual variation is important, and suggests increasing nest densities over the 2000-2003 study period.

\section{Nest initiation}

Spring ice break-up was late in both the Hopedale and Nain archipelagos during 2002. We found a significant interaction between archipelago and year with respect to nest initiation date, with Rigolet in the south showing relatively consistent timing, and the two northern archipelagos showing greater annual variation.

Earlier, we documented that nest initiation dates in Labrador were positively related to lat-

Table 3. Summary of general linear model analysis by variable for nesting characteristics of common eiders breeding in Labrador, 2000-2003.

\begin{tabular}{|c|c|c|c|c|c|}
\hline Variable & $\begin{array}{c}\text { Model fit } \\
\mathrm{R}^{2} \text {-adjusted (\%) }\end{array}$ & Factors & $\mathrm{df}$ & $\mathrm{F}$ & $\mathrm{p}$ \\
\hline \multirow[t]{4}{*}{ Nest density } & \multirow[t]{4}{*}{90.3} & Year & 3 & 4.2 & $<0.01$ \\
\hline & & Archipelago & 2 & 3.9 & 0.02 \\
\hline & & $\begin{array}{l}\text { Year-archipelago } \\
\text { interaction }\end{array}$ & 6 & 1.1 & 0.36 \\
\hline & & $\begin{array}{l}\text { Island nested in } \\
\text { archipelago }\end{array}$ & 165 & 17.9 & $<0.01$ \\
\hline \multirow[t]{4}{*}{ Nest initiation } & \multirow[t]{4}{*}{72.6} & Year & 2 & 42.7 & $<0.01$ \\
\hline & & Archipelago & 2 & 62.1 & $<0.01$ \\
\hline & & $\begin{array}{l}\text { Year-archipelago } \\
\text { interaction }\end{array}$ & 4 & 7.1 & $<0.01$ \\
\hline & & $\begin{array}{l}\text { Island nested in } \\
\text { archipelago }\end{array}$ & 63 & 2.4 & $<0.01$ \\
\hline \multirow[t]{4}{*}{ Clutch size } & \multirow[t]{4}{*}{6.6} & Year & 3 & 3.5 & $<0.01$ \\
\hline & & Archipelago & 2 & 9.4 & 0.01 \\
\hline & & $\begin{array}{l}\text { Year-archipelago } \\
\text { interaction }\end{array}$ & 6 & 10.1 & $<0.01$ \\
\hline & & $\begin{array}{l}\text { Island nested in } \\
\text { archipelago }\end{array}$ & 116 & 4.7 & $<0.01$ \\
\hline \multirow[t]{2}{*}{ Egg volume } & \multirow[t]{2}{*}{6.1} & Archipelago & 3 & 5.5 & $<0.01$ \\
\hline & & $\begin{array}{l}\text { Island nested in } \\
\text { archipelago }\end{array}$ & 43 & 1.1 & 0.27 \\
\hline \multirow[t]{2}{*}{ Clutch volume } & \multirow[t]{2}{*}{11.5} & Archipelago & 3 & 0.8 & 0.44 \\
\hline & & $\begin{array}{l}\text { Island nested in } \\
\text { archipelago }\end{array}$ & 43 & 2.0 & $<0.01$ \\
\hline
\end{tabular}


Fig. 5.: Interval plot of mean egg and clutch volume $\left(\mathrm{cm}^{3}\right)$ by archipelago with $95 \% \mathrm{CI}$.

Horizontal lines are equal to the overall means.
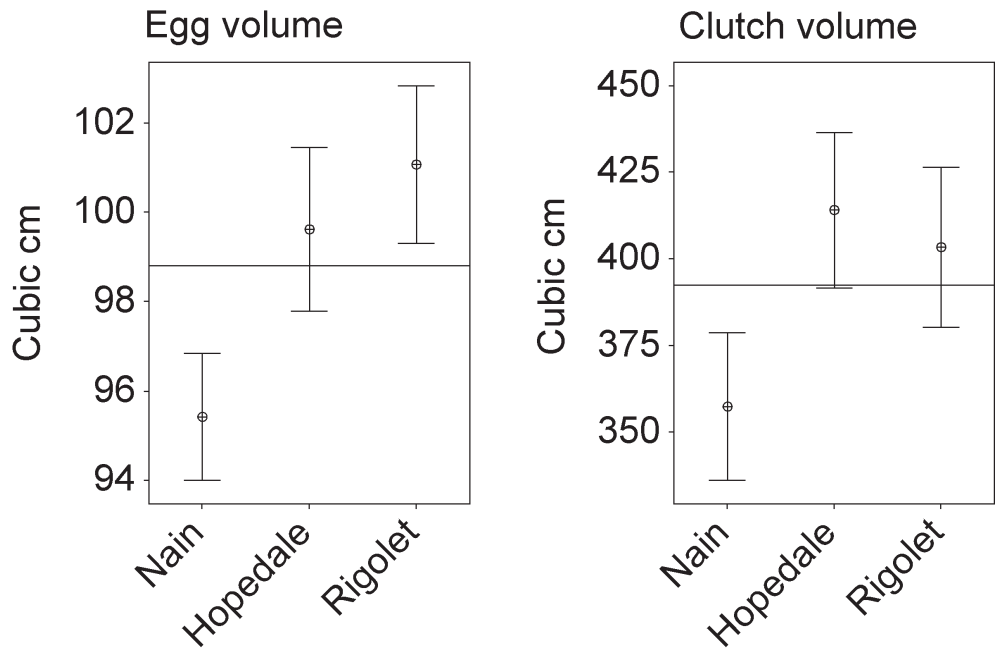

itude, but we were not able to test year effects (Chaulk et al. in press). This latitudinal pattern still holds over multiple years, but there can be substantial between-year variation in the timing of nest initiation. This highlights the importance of multi-year studies, especially for those aspects of breeding ecology that can be easily influenced by biophysical factors, such as sea ice break-up in the spring (Laurila \& Hario 1988; Goudie et al. 2000). Given that we found an interaction between archipelago and year in nest initiation date, it is likely that nest initiation date is influenced by ice conditions at the local level. It is important to recognize that common eider nest initiation can be influenced by annual variation in the timing of spring break-up. This could mean that common eiders are a potentially good species for monitoring the effects of climate change in this region of North America, but our results show that more than one site would need to be monitored.

\section{Clutch size}

Clutch size is often used as a comparative measure between different populations (Lewis 1939; Milne 1974; Swennen 1983; Coulson 1984; Robertson et al. 2001; Bregnballe 2002; Chaulk et al. in press). Common eider clutch size is influenced by female body condition, food availability, disease, body parasites, severity of winter, timing of spring, predation and nest parasitism (Rohwer 1992, Erikstad, Bustnes et al. 1993).
Some researchers have suggested that average clutch size may increase during population growth (Hario \& Selin 1988), whereas other have found no such trend (Swennen 2002).

Our analysis revealed a significant interaction of archipelago and year on clutch size, indicating that any annual patterns were not matched across regions. However, our model had a low $\mathrm{R}^{2}$ value; therefore a significant amount of variability remains unexplained by either archipelago, year or their interaction. Interestingly, Bregnballe (2002) did find that clutch size varied across years in a similar way across five colonies in Denmark. At a larger spatial scale, Coulson (1999) found that clutch size varied independently across years between Scottish and Dutch colonies. Clearly, the geographic scale of the analysis appears to be important. Previously, we found significant archipelago differences in clutch size but this finding was based on analysis of one year of data (Chaulk et al. in press). Annual and regional variation in clutch size is not surprising. Our new findings suggest that average clutch size varies by archipelago and year at the scale of coastal Labrador, and we do not recommend the use of single measures (i.e., one archipelago and/ or year) of clutch size as a basis to assess population productivity. Instead long-term measurements over several archipelagos are needed for robust comparisons between different populations. 


\section{Egg and clutch volume}

Some studies have shown that annual variation in eider egg volume is limited (Swennen \& van der Meer 1992; Robertson 1995; Laurila \& Hario 1998; Hanssen et al. 2002). As such, egg volume may hold value as a comparative measure between populations at large geographic scales (Robertson et al. 2001). In 2003, egg volume differed significantly by archipelago, but not by island, whereas clutch volume differed by island but not by archipelago. Clutch volume is largely influenced by clutch size, and likely has limited value as a comparative measure between archipelagos (see above). Our data support the idea that average egg volume has merit to assess population structure at moderate geographic scales (i.e., 100s of $\mathrm{km}$ ). But with only one year of data and low $\mathrm{R}^{2}$ values for our egg and clutch volume models additional data are required to assess spatial and temporal interactions.

Using values presented in Goudie et al. (2000) we calculated average egg volumes for two subspecies of common eiders in North America (borealis $=96.4 \pm 4.4 \mathrm{~cm}^{3}$, range $=93.8-102.8 ;$ dresseri $=108.0 \pm 5.5$, range $=100.6-115.8$ ). Based on an examination of these values it appears that egg volumes from Nain were most similar to those of borealis, while the values for Hopedale and Rigolet were on the high end for borealis and on the low end for dresseri. This pattern is likely the result of intergradation between borealis and dresseri in the zone of overlap that is considered to occur in both Hopedale and Rigolet (Mendall 1980; Chaulk et al. in press). Egg volume followed a latitudinal pattern with eiders from Rigolet in the south having the largest egg volumes and eiders from Nain in the north having the smallest.

Finally, we feel the need to comment on our sampling scheme, as the average size of sampled islands was significantly lower than the average size of islands in each archipelago. We actively excluded islands larger than 30 ha from our surveys. We did this for logistical reasons. Large islands require significant effort to search, so instead we focused on smaller islands that could be easily censused by small field crews over restricted time periods. Goudie et al. (2000) reported that common eiders preferred nesting on islands $<75-100$ ha. Other researchers have used island size thresholds to help identify islands for investigation during eider breeding research (Nakashima \& Murray 1988; Robertson \& Gil- christ 1998; Merkel 2004) or focused on small islands during breeding surveys (Korschgen 1977; Götmark \& Åhlund 1984). It is possible that omitting islands $>30$ ha has impacted our results, most likely with respect to our estimates of nest density and percentage of occupied islands. In addition, larger islands might have greater vegetative coverage, and cover has been shown to increase nest success (Choate 1967; Milne 1974; Schmutz et al. 1983), and nest success could in turn impact some of the breeding characteristics that we discuss in this paper. Since we lack data from islands $>30$ ha we have no way of knowing the magnitude or direction of these differences. However, our personal observations and discussions with local aboriginal people support the idea that eiders breeding on the mid-Labrador coast rarely use large islands (>30 ha) for nesting. We recognize that the spatial structuring and the biophysical characteristics of eider breeding islands are important, but these variables are beyond the scope of this paper. We hope to investigate habitat requirements of common eiders breeding in Labrador in future research.

\section{Conclusions}

To summarize our findings, when annual effects were detected, they often interacted with regional effects. Based on the inter-annual and interregional variation, as well as their interactions, long-term surveys over wide geographic regions are needed for comprehensive understanding of population dynamics and responses to environmental changes. Such understanding is needed for sound management decisions. For example, large clutch sizes and early breeding could lead to a liberalization of hunting regulations given the expected large number of young birds in the fall flight. Conversely, reduced clutches and late breeding might be used as rationale to reduce harvest quotas and limit hunting seasons. However, if only one site is assessed, our results suggest that these indicators of breeding conditions would not be representative for an entire breeding range. Finally, egg volume does not appear to vary between islands at small geographic scales (i.e., within an archipelago), but does vary at moderate geographic scales (i.e., 100s of km) and could hold promise as an indicator of population genetic differences (Robertson et al. 2001). 
Acknowledgements.-Special thanks to B. Turner (Canadian Wildlife Service); N. Anderson, K. Dicker, D. Pottle, W. Wolfrey (Fisheries and Oceans Canada); J. Rowell, B. Anderson, W. Hunter, I. Winters, E. Merkuratsuk, D. Wolfrey (Labrador Inuit Association). Special thanks also go to Shawn Broomfield for help in preparing the data for analysis. The Labrador Inuit Association, the Canadian Wildlife Service, the Northern Ecosystem Initiative, the Northern Scientific Training Program, Memorial University of Newfoundland, and INCO provided funding for this study. We also thank A. Mosbech and S. Hanssen for their very helpful comments.

\section{References}

Abraham, K. F. \& Finney, G. H. 1986: Eiders of the eastern Canadian Arctic. In A. Reed (ed.): Eider ducks in Canada. Can. Wildl. Serv. Rep. Ser. 47, 55-73.

Avise, J. C. \& Hamrick, J. L. (eds.) 1996: Conservation Genetics. London: Chapman \& Hall.

Bregnballe, T. 2002: Clutch size in six Danish common eider Somateria mollissima colonies: variation in egg production. In H. Noer \& G. Nehls (eds.): Population processes in the common eider Somateria mollissima. Danish Review of Game Biology 16. Rønde, Denmark.

Chapdelaine, G., Dupuis, P. \& Reed, A. 1986: Distribution, abundance et fluctuations des populations d'Eider à Duvet dans l'estuaire et le golfe du Saint-Laurent. (Distribution, abundance, and fluctuation of eider populations in the St. Lawrence estuary and gulf). In A. Reed (ed.): Eider ducks in Canada. Can. Wildl. Serv. Rep. Ser. 47, 6-11.

Chaulk, K. G., Robertson, G. J., Montevecchi, W. A. \& Ryan, P. C. in press: Aspects of common eider nesting ecology in Labrador. Arctic.

Choate, J. S. 1967: Factors influencing nesting success of eiders in Penobscot Bay, Maine. J. Wildl. Manage. 31, 769-777.

Cooch, F. G. 1986: The numbers of nesting northern eiders on the West Foxe islands, NWT, in 1956 and 1976. In A. Reed (ed.): Eider ducks in Canada. Can. Wildl. Serv. Rep. Ser. 47, 114-118.

Coulson, J. C. 1984: The population dynamics of the eider duck Somateria mollissima and evidence of extensive nonbreeding by adult ducks. Ibis 126, 525-543.

Coulson, J. C. 1999: Variation in clutch size of the common eider: a study based on 41 breeding seasons on Coquet Island, Northumberland, England. Waterbirds 22, 225-238.

Erikstad, K. E., Bustnes, J. O. \& Moum, T. 1993: Clutch-size determination in precocial birds: a study of the common eider. Auk 110, 623-628.

Erikstad, K. E., Tveraa, T. \& Bustnes, J. O. 1998: Signficance of intraclutch egg-size variation in common eider: the role of egg size and quality of ducklings. J. Avian Biol. 29, 3-9.

Falardeau, G., Rail, J.-F., Gilliland, S. \& Savard, J.-P. L. 2003 Breeding survey of common eiders along the west coast of Ungava Bay, in summer 2000, and a supplement on other nesting aquatic birds. Can. Wildl. Serv. Tech. Rep. Ser. No. 405 .

Götmark, F. \& Åhlund, M. 1984: Do field observers attract nest predators and influence nesting success of common eiders. J. Wildl. Manage. 48, 381-387.

Goudie, R. I., Robertson, G. J. \& Reed, A. 2000: Common eider (Somateria mollissima). The birds of North America
(A. Poole \& F. Gill, eds.) 546. Philadelphia, The Birds of North America Inc.

Guild, B. L. 1974: The breeding biology of the Hudson Bay Eider at La Pérouse Bay, Manitoba. M.Sc. thesis. Wright State University, Dayton, OH.

Hanssen, S. A., Folstad, I. \& Erikstad, K. E. 2002: Incubation start and egg size in relation to body reserves in the common eider. Behav. Ecol. Sociobiol. 52, 282-288.

Hanssen, S. A., Folstad, I. \& Erikstad, K. E. 2003: Reduced immunocompetence and cost of reproduction in common eiders. Oecologia 136, 457-464.

Hario, M. \& Selin, K. 1988: Thirty-year trends in an eider population: timing of breeding, clutch size and nest preferences. Finn. Game Res. 45, 3-10.

Hario, M. \& Selin, K. 2002: Cohort-specific differences in reproductive output in a declining common eider Somateria mollissima population. In H. Noer \& G. Nehls (eds.): Population processes in the common eider Somateria mollissima. Danish Review of Game Biology 16. Rønde, Denmark.

Korschgen, C. E. 1977: Breeding stress of female eiders in Maine. J. Wildl. Manage. 41, 360-373.

Lack, D. 1967: The significance of clutch size in waterfowl Wildfowl 18, 125-128.

Laurila, T. \& Hario, M. 1988. Environmental and genetic factors influencing clutch size, egg volume, date of laying and female weight in the common eider Somateria mollissima. Finn. Game Res. 45, 19-30.

Lewis, H. F. 1939: Size of sets of eggs of the American eider. J. Wildl. Manage. 3, 70-73.

Lopoukhine, N., Prout, N. A. \& Hirvonen, H. E. 1978: The ecological land classification of Labrador: a reconnaissance. Environment Canada, Series 4.

Meades, S. J. 1990: Natural regions of Newfoundland and Labrador. St. John's, Newfoundland: Protected Areas Association of Newfoundland and Labrador.

Mendall, H. L. 1980: Intergradation of eastern North American common eiders. Can. Field Nat. 94, 286-292.

Merkel, F. R. 2004: Evidence of population decline in common eiders breeding in western Greenland. Arctic 57, 27-36.

Milne, H. 1974: Breeding numbers and reproductive rate of eiders at the Sands of Forvie National Nature Reserve, Scotland. Ibis 116, 135-154.

Mohr, C. O. 1947: Table of equivalent populations of North American small mammals. Am. Midl. Nat. 37, 223-249.

Nakashima, D. J. \& Murray, D. J. 1988: The common eider (Somateria mollissima mollissima) of eastern Hudson Bay: a survey of nest colonies and Inuit ecological knowledge. Environ. Stud. Revolv. Funds Rep. 102

Nettleship, D. N. 1980: Census techniques for seabirds of arctic and eastern Canada. Canadian Wildlife Service Occasional Paper 25. Ottawa.

Nettleship, D. N. \& Evans, P. G. H. 1985: Distribution and status of Atlantic alcidae. In D. N. Nettleship \& T. R. Birkhead (eds.): The Atlantic Alcidae. Pp. 53-154 London: Academic Press.

Robertson, G. J. 1995: Annual variation in common eider egg size: effects of temperature, clutch size, laying date, and laying sequence. Can. J. Zool. 73, 1579-1587.

Robertson, G. J. \& Gilchrist, H. G. 1998: Evidence of population declines among common eiders breeding in the Belcher Islands, Northwest Territories. Arctic 51, 378-385.

Robertson, G. J. Reed, A. \& Gilchrist, H. G. 2001: Clutch, egg and body size variation among common eiders breeding in Hudson Bay, Canada. Polar Res. 20, 85-94. 
Rohwer, F. C. 1992: The evolution of reproductive parameters in waterfowl. In B. D. Batt et al. (eds.): Ecology and management of breeding waterfowl. Pp. 486-539. Minneapolis: Univ. Minnesota Press.

Ryder, J. P. 1970: A possible factor in the evolution of clutch size in Ross' goose. Wilson Bull. 82, 5-13.

Schmutz, J. K., Robertson R. J. \& Cooke, F. 1983: Colonial nesting of the Hudson Bay eider duck. Can. J. Zool. 61, 2424-2433.

Scott, J. M., Heglund, P. J., Morrison, M. L., Haufler, J. B., Raphael, M. G., Wall, W. A. \& Samson, F. B. (eds.). 2002: predicting species occurrences: issues of accuracy and scale. Covelo, CA: Island Press.

Sokal, R. R. \& Rohlf, F. J. 1995: Biometry: the principles and practice of statistics in biological research. Third edition. San Francisco: W.H. Freeman and Company.

Swennen, C. 1983: Reproductive output of eiders (Somateria mollissima mollissima) on the southern border of its breeding range. Ardea $71,245-254$.

Swennen, C. \& van der Meer, J. 1992: Variation in egg size of common eiders. Ardea 80, 363-373.

Swennen, C. 2002: Development and population dynamics of common eider Somateria mollissima colonies in the Netherlands. In H. Noer \& G. Nehls (eds.): Population processes in the common eider Somateria mollissima. Danish Review of Game Biology 16. Rønde, Denmark.

Weller, M. W. 1956: A simple field candler for waterfowl eggs. J. Wildl. Manage. 20, 111-113. 